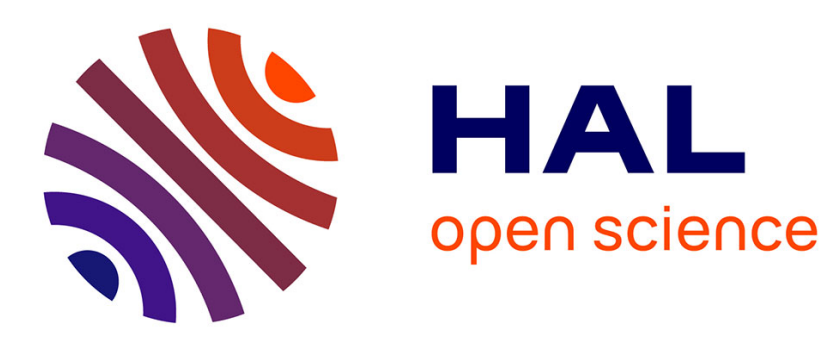

\title{
Doping and calcination effect on nanostructured aluminosilicates processed by sol-gel route
}

\author{
Sunil Simon, M. Tămăşan, T. Radu, V. Simon
}

\section{To cite this version:}

Sunil Simon, M. Tămăşan, T. Radu, V. Simon. Doping and calcination effect on nanostructured aluminosilicates processed by sol-gel route. European Physical Journal: Applied Physics, 2011, 55 (3), 10.1051/epjap/2011100524 . hal-00724135

\section{HAL Id: hal-00724135 \\ https://hal.science/hal-00724135}

Submitted on 18 Aug 2012

HAL is a multi-disciplinary open access archive for the deposit and dissemination of scientific research documents, whether they are published or not. The documents may come from teaching and research institutions in France or abroad, or from public or private research centers.
L'archive ouverte pluridisciplinaire HAL, est destinée au dépôt et à la diffusion de documents scientifiques de niveau recherche, publiés ou non, émanant des établissements d'enseignement et de recherche français ou étrangers, des laboratoires publics ou privés. 


\title{
Doping and calcination effect on nanostructured aluminosilicates processed by sol- gel route
}

\author{
S. Simon, M. Tămăşan, T. Radu, V. Simon* \\ Babes-Bolyai University, Faculty of Physics \& Institute for Interdisciplinary \\ Research in Bio-Nano-Sciences, 400084 Cluj-Napoca, Romania
}

\begin{abstract}
Local order changes determined in an aluminosilicate matrix by calcination and addition of iron, yttrium or dysprosium oxides were investigated by X-ray diffraction and infrared spectroscopy. The nanocrystalline phase is reached only by Fe doping and not by the other two dopings. After calcination at temperatures as high as $1200{ }^{\circ} \mathrm{C}$, nanocrystalline cristobalite alone are formed in the aluminosilicate matrix, while the doped samples favour the additional growth of mullite and quartz nanocrystals. The aluminosilicate spinel phase was not detected in any of these samples. An additional crystalline phase was only observed in the samples doped with yttrium and dysprosium. The structural units evidenced by FTIR analysis are associated with the crystalline phases identified by X-ray diffraction.
\end{abstract}

\section{Introduction}

Aluminosilicate systems synthesised at room temperature by sol-gel route present attractive properties for medical application as biomaterials [1-3], but also as catalysts [4, 5]. In addition to chemical composition, the structure, surface topographical features and the nanoscale changes in surface layer all have significant effects on their bioactive and catalytic properties [4-6].

Sol-gel derived aluminosilicates with nanosised mullite particles are interesting candidates for osteoconductive coatings on alumina implants [7]. Biocompatible ferrimagnetic glass ceramics are suitable for hysteresis heating of surrounding tissues [8].

*Corresponding author: viosimon@phys.ubbcluj.ro 
Silicate and aluminosilicate glass ceramics are highly stable in the body, therefore, by the addition of iron oxide they could be optimised for hysteresis heating [9-11]. Hyperthermia is part of non-invasive protocols for cancer therapy and is considered a promising treatment for tumour eradication $[12,13]$. On the other hand, aluminosilicate glasses with yttrium or certain rare earths like dysprosium, samarium and holmium have led to a special family of glasses used in internal radiotherapy [14, 15]. The biocompatibility of these materials depends on the activity of the cells adhered to their surface and is influenced not only by the composition of the materials but also by their structure. Moreover, the studies have emphasized that nanosized crystalline phases, like nanosized mullite, can increase the cells function in comparison to conventional phases, but it is considered that a spinel phase diminishes the activity of the cells adhered onto these samples surface [7].

In this paper we report results concerning local order changes in a sol-gel derived aluminosilicate matrix determined by calcination and the addition of iron, yttrium or dysprosium oxides.

\section{Experimental}

Experimental samples of $75 \mathrm{SiO}_{2} \cdot(25-\mathrm{x}) \mathrm{Al}_{2} \mathrm{O}_{3} \cdot \mathrm{xM}_{2} \mathrm{O}_{3}$ system, where $\mathrm{M}=\mathrm{Fe}, \mathrm{Y}$ or Dy, and $\mathrm{x}=0 ; 5 \mathrm{~mol} \%$, were prepared by the sol-gel method using, as starting reagents, $\mathrm{Si}(\mathrm{OH})_{4}, \mathrm{Al}\left(\mathrm{NO}_{3}\right)_{3} \cdot 9 \mathrm{H}_{2} \mathrm{O}, \mathrm{Fe}\left(\mathrm{NO}_{3}\right)_{3} \cdot 9 \mathrm{H}_{2} \mathrm{O}, \mathrm{Y}\left(\mathrm{NO}_{3}\right)_{3} \cdot 6 \mathrm{H}_{2} \mathrm{O}$ and $\mathrm{Dy}\left(\mathrm{NO}_{3}\right)_{3} \cdot 5 \mathrm{H}_{2} \mathrm{O}$. Silicic acid $\mathrm{Si}(\mathrm{OH})_{4}$ was dissolved in distilled water and mixed at room temperature for 30 minutes. After the addition of $\mathrm{Al}\left(\mathrm{NO}_{3}\right)_{3} \cdot 9 \mathrm{H}_{2} \mathrm{O}$ water solution the mixture was stirred for 30 minutes at $90{ }^{\circ} \mathrm{C}$, and finally the $\mathrm{M}\left(\mathrm{NO}_{3}\right)_{3} \cdot n \mathrm{H}_{2} \mathrm{O}$ water solution was added. As the mixture appeared like a gel, it was filtered and dried in an electric oven at $110{ }^{\circ} \mathrm{C}$ for 2 hours. The $\mathrm{pH}$ of the prepared samples was 8.4. The dried samples were then calcinated at $500{ }^{\circ} \mathrm{C}$ for 1 hour and $1200{ }^{\circ} \mathrm{C}$ for 24 hours. 
DTA/TG measurements were performed on a Shimadzu analyser DTG-60H, from room temperature to $1200{ }^{\circ} \mathrm{C}$, in air, using alumina crucibles, with a heating rate of $10^{\circ} \mathrm{C} / \mathrm{min}$. The structure of the calcinated samples was investigated by X-ray diffraction with a Shimatzu XRD- 6000 diffractometer, using CuKa radiation $(\lambda=1.5418 \AA$ Á), with Nifilter. The FTIR spectra were recorded with a resolution of $2 \mathrm{~cm}^{-1}$ on an Equinox 55 Bruker spectrophotometer, at room temperature, using the $\mathrm{KBr}$ disk technique.

\section{Results and discussion}

The DTA/TG profiles are shown in Fig. 1. The endothermic peaks, accompanied by significant weight losses, are attributed to water removal, decomposition of the remaining nitrate groups and dehydroxylation process [16-18]. The analysis of TG runs shows that the preponderant weight loss takes place below $500{ }^{\circ} \mathrm{C}$. At temperatures above this limit the weight loss is less significant. Therefore, the first calcination was at $500{ }^{\circ} \mathrm{C}$. The weak exothermic peaks indicate rearrangements in the xerogel structure and could even denote an amorphous phase separation which subsequently at higher temperatures leads to crystallisation of different phases $[19,20]$.

The X-ray diffraction patterns of the $500{ }^{\circ} \mathrm{C}$ calcinated samples (Fig. 2) show that they are amorphous, except for the iron doped sample (Fig. 2b), whereas minor hematite and magnetite nanocrystalittes are evidenced by the peaks at $2 \theta=33.3,35.8,49.8$ and $54.7^{\circ}$ [21-23]. In order to enhance the crystallisation process, a second calcination was applied at $1200{ }^{\circ} \mathrm{C}$.

After 24 hours of calcination at $1200{ }^{\circ} \mathrm{C}$, only a nanocrystalline phase of $\mathrm{SiO}_{2}$ cristobalite type [24] developed in the aluminosilicate matrix (Fig. 3a). The absence of any other crystalline phases with aluminium proved that aluminium ions are mainly incorporated in the remaining non-crystalline phase. The crystalline silica can appear in different polymorphic forms as quartz, tridymite and cristobalite, each of them representing a 
distinct arrangement of silicon-oxygen tetrahedra in the three-dimensional crystalline network. The diffraction peaks at $2 \theta=20.8$ and $26.7^{\circ}$, for samples with yttrium and dysprosium, are a contribution from a crystalline $\mathrm{SiO}_{2}$ quartz phase $[25,26]$. In the doped samples (Fig. 3 b-d), diffraction peaks arising from $\mathrm{Al}_{6} \mathrm{Si}_{2} \mathrm{O}_{13}$ mullite nanocrystals [20, 27, 28] are recorded besides cristobalite nanocrystals. Mullite is a biocompatible ceramic phase with soft and hard tissues, and nanosized mullite can increase the cells function while a spinel phase diminishes the activity of the cells $[7,29]$. Metastable phases like aluminosilicate spinel did not appear in any of our samples. An additional unidentified diffraction peak, marked with asterisk, is recorded only from the yttrium and dysprosium doped samples. This peak is assumed to be related with a structural phase including the larger radius $\mathrm{Y}^{3+}$ and $\mathrm{Dy}^{3+}$ ions, about $1.05 \AA$, compared with 0.69 and $0.75 \AA$ - the radius of $\mathrm{Fe}^{3+}$ and $\mathrm{Fe}^{2+}$ ions respectively. The iron ions could be easily included in mullite phase, their radii being close to that of $\mathrm{Al}^{3+}$ ion $\left(0.53 \AA\right.$ for $\mathrm{Al}^{3+}$ tetracoordinated and $0.68 \AA$ for $\mathrm{Al}^{3+}$ hexacoordinated) [30]. Crystal size estimation from the XRD peaks width shows that the size of the developed nanocrystals range from 10.4 to $30.5 \mathrm{~nm}$ depending on the doping oxide.

FTIR analysis was performed in the wave number region range of $4000-400 \mathrm{~cm}^{-1}$. The spectra of $500{ }^{\circ} \mathrm{C}$ calcinated samples (Fig. 4) appear very similar. The absorption bands around 3420 and $1635 \mathrm{~cm}^{-1}$ are usually attributed to symmetrical and asymmetrical $\mathrm{O}-\mathrm{H}$ stretching vibrations, and respectively to the bending of $\mathrm{H}-\mathrm{O}-\mathrm{H}$ from water molecules adsorbed on the sample surface. The broad absorption band appearing at $1110 \mathrm{~cm}^{-1}$, with a shoulder at $1215 \mathrm{~cm}^{-1}$, is ascribed to $\mathrm{Si}-\mathrm{O}$ stretching vibration $\left(\mathrm{SiO}_{4}\right)$ and asymmetric stretching vibration of Si-O-Si bonds [31]. The weak absorption band recoded at 800 $\mathrm{cm}^{-1}$ can be assigned to amorphous silica [32, 33] and tetracoordinated aluminium [34]. The absorption band at around $475 \mathrm{~cm}^{-1}$ is characteristic of $\mathrm{Si}-\mathrm{O}-\mathrm{Si}$ bending vibration and $\mathrm{Al}-\mathrm{O}-\mathrm{Al}$ bending vibration $[35-37]$. 
After calcination at $1200{ }^{\circ} \mathrm{C}$, the FTIR spectra (Fig. 5) appear among each other less similar than those of $500{ }^{\circ} \mathrm{C}$ calcinated samples (Fig. 4). Beside the 3430 and $1636 \mathrm{~cm}^{-1}$ absorption bands occurring from $\mathrm{O}-\mathrm{H}$ stretching mode and $\mathrm{H}-\mathrm{O}-\mathrm{H}$ bending mode of molecular water, for all samples are recorded IR absorption bands close to 1205, 1095, 890, 790, 720, 620, 575 and $480 \mathrm{~cm}^{-1}$, which isbetter evidenced in Fig. 6. Some of these bands $\left(1205,1095,790\right.$ and $\left.480 \mathrm{~cm}^{-1}\right)$ occur at wavenumbers very close to that of the bands recorded from non-crystalline samples and have the same assignments. For example, the weak peak at $800 \mathrm{~cm}^{-1}$ band (Fig. 4) assigned to amorphous silica occurs shifted to $790 \mathrm{~cm}^{-1}$ (Fig. 5), and is due to symmetric Si-O-Si stretching vibration in crystalline $\mathrm{SiO}_{2}[32,33,38]$.

The following IR absorption bands of $1200{ }^{\circ} \mathrm{C}$ crystallised samples are new: 575, 620, 720 and $890 \mathrm{~cm}^{-1}$. The weak band at $575 \mathrm{~cm}^{-1}$ is assigned to Al-O stretching vibration in $\mathrm{AlO}_{6}$ units, the shoulder at $720 \mathrm{~cm}^{-1}$ is attributed to $\mathrm{Al}-\mathrm{O}$ stretching vibration in $\mathrm{AlO}_{4}$ units [39], and the band at $620 \mathrm{~cm}^{-1}$ occurs from O-Al-O bending vibration. The large absorption band recorded around $890 \mathrm{~cm}^{-1}$ only from the doped samples (Fig. $6 \mathrm{~b}-\mathrm{d}$ ) is assigned to Al-O stretching vibration in $\mathrm{AlO}_{4}$ units $[40,41]$. On the other hand, only in the spectra of yttrium an dysprosium samples (Fig. $5 \mathrm{c}, \mathrm{d}$ ) a very weak shoulder is recorded at $960 \mathrm{~cm}^{-1}$, which can be related to the unassigned X-ray diffraction peak (Fig. 3) obtained only for these two samples.

\section{Conclusions}

Vitreous $3 \mathrm{SiO}_{2} \cdot \mathrm{Al}_{2} \mathrm{O}_{3}$ aluminosilicate matrix was obtained using the low temperature solgel route, followed by calcination at $500{ }^{\circ} \mathrm{C}$. By doping with $\mathrm{M}_{2} \mathrm{O}_{3}(\mathrm{M}=\mathrm{Fe}, \mathrm{Y}$ or Dy $)$ only Fe creates the nanocrystalline phase, the other two dopings do not. While the 1200 ${ }^{\circ} \mathrm{C}$ calcination induces in the aluminosilicate matrix exclusively the growth of $\mathrm{SiO}_{2}$ cristobalite nanocrystalline phase, all the doped samples favour the development of nanocrystals of $\mathrm{SiO}_{2}$ quartz and $\mathrm{Al}_{6} \mathrm{Si}_{2} \mathrm{O}_{13}$. The occurrence of the mullite phase suggests 
the separation of an aluminium rich vitreous phase during the heating process of $\mathrm{M}_{2} \mathrm{O}_{3}$ containing samples. In addition, an unidentified crystalline phase is formed in the samples containing yttrium and dysprosium. In none of these samples do undesired metastable phases like aluminosilicate spinel appear, which could diminish the activity of the cells adhered to their surface.

FTIR results validate these structural changes by occurrence of new absorption bands assigned to bond vibrations in the $\left(\mathrm{SiO}_{4}\right),\left(\mathrm{AlO}_{4}\right)$ and $\left(\mathrm{AlO}_{6}\right)$ structural units. The investigated aluminosilicate samples present suitable nanostructural features that could favor their application as biomaterials.

\section{Acknowledgements}

This research was accomplished in the framework of PNII Idei PCCE-76/2008 project granted by the Romanian National University Research Council - CNCSIS. 


\section{References}

1. J. Leivo, M. Linden, M. Ritola, M. Vippola, E. Levanen, T.A. Mantyla, Mater. Chem. Phys. 115, 56 (2009)

2. P. Gershkovich, J. Darlington, O. Sivak, P.P.Constantinides, K.M. Wasan, J. Pharmacol. Sci. 98, 2390 (2009)

3. H. Oudadesse, A.C. Derrien, M. Mami, S. Martin, G. Cathelineau, L. Yahia, Biomed. Mater. 2, S59 (2007)

4. G.S. Machado, K.A. de Freitas Castro, O.J. de Lima, E.J.Nassar, K. J. Ciuffi, S. Nakagaki, Colloid Surface A 349, 162 (2009)

5. R.S. Araujo, D.C.S. Azevedo, E. Rodriguez-Castellon, A. Jimenez-Lopez, C.L. Cavalcante Jr., J. Mol. Catal. A- Chem. 281, 154 (2008)

6. R. Viitala, M. Jokinen, T. Peltola, K. Gunnelius , J.B. Rosenholm, Biomaterials 23, 3073 (2002)

7. J. Leivo, V. Meretoja, M.Vippola, E. Levanen, P.Vallittu, T.A. Mantyla, Acta Biomat. 2, 659 (2006)

8. M. Kawashita, H. Takaoka, T. Kokubo, T. Yao, S. Hamada, T. Shinjo, J. Ceram. Soc. Jpn. 109,39 (2001)

9. S.A.M. Abdel-Hameed, M.M. Hessien, M.A. Azooz, Ceram. Int. 35, 1539 (2009)

10. V. Simon, S. Cavalu, S. Simon, H. Mocuta, E. Vanea, M. Prinz, M. Neumann, Solid State Ionics 180, 764 (2009)

11. D. Eniu, D. Cacaina, M. Coldea, M. Valeanu, S. Simon, J. Magn. Magn. Mater. 293 (2005) 310.

12. O. Bretcanu, S. Spriano, E. Verne, M. Coisson, P. Tiberto, P. Allia, Acta Biomater. 1 (2005) 421.

13. K.A. Gross, R. Jackson, J.D. Cashion, L.M. Rodriguez-Lorenzo, Eur. Cell Mater. 3 S2, 114 (2002)

14. G.J. Ehrhardt, D.E. Day, Nucl. Med. Biol. 14, 233 (1987)

15. R.F. Brown, L.C. Lindesmith, D.E. Day, Nucl. Med. Biol. 18, 783 (1991)

16. V. Simon, D. Eniu, A. Gritco, S. Simon, J. Optoelectron. Adv. Mater. 9, 3368 (2007)

17. M. Tamasan, T. Radu, S. Simon, I. Barbur, H. Mocuta, V. Simon, J. Optoelectron. Adv. Mater. 10, 948 (2008)

18. L. Xia, G. Wen, L. Song, X. Wang, Mat. Chem. Phys. 119, 495 (2010) 
19. T. Takei, Y. Kameshima, A. Yasumori, K. Okada, J. Eur. Ceram. Soc. 21, 2487 (2001)

20. F. He, W.T. Petuskey, Mater. Lett. 63, 2631 (2009)

21. Y. Sun, L. Duan, Z. Guo, Y. Duanmu, M. Ma, L. Xu, Y. Zhang, N. Gu, J. Magn. Magn. Mater. 285, 65 (2005)

22. T. Chen, H. Xu, Q. Xie, J. Chen, J. Ji, H. Lu, Earth Planet. Sc. Lett. 240, 790 (2005)

23. Th. Leventouri, A.C. Kis, J.R. Thompson, I.M. Anderson, Biomaterials 26, 4924 (2005)

24. S.H. Hyun, S.C. Yi, S.G. Kim, J. Mat. Sci. Lett. 15, 1384 (1996)

25. J. Amigo, F.J. Serrano, M.A. Kojdecki, J. Bastida, V. Esteve, M.M. Reventos, F. Marti, J. Eur. Ceram. Soc. 25, 1479 (2005)

26. D. Ikuta, N. Kawame, S. Banno, T. Hirajima, K. Ito, J.F. Rakovan, R.T. Downs, O. Tamada, Am. Mineral. 92, 57 (2007)

27. D. Balzar, H. Ledbetter, Am. Mineral. 78, 1192 (1993)

28. P. Hou, S.N. Basu, V.K. Sarin, J. Mater. Res. 14, 2952 (1999)

29. W.C. Richardson Jr, J.J. Klawitter, B.W. Sauer, J.R. Pruitt, S.F. Hulbert, J. Biomed. Mater. Res. 9, 73 (1975)

30. D.R. Lide (Ed.), Handbook of Chemistry and Physics, 81-st edn. (CRC Press, Boca Raton, Florida, USA, 2000)

31. W.K.W. Lee, J.S.J. van Deventer, Langmuir 19, 8726 (2003)

32. V.C. Farmer, A.R. Fraser, J.M. Tait, Geochem. Cosmochem. 43, 1417 (1979)

33. J. Ojima, J. Occup. Health 45, 94 (2003)

34. E.I. Basaldella, R.M. Torres Sanchez, J.C. Tara, Clay Clay Miner. 46, 481 (1998)

35. B.N. Roy, J. Am. Ceram. Soc. 70, 183 (1987)

36. D. Voll, P. Angerer, A. Beran, H.Schneider, Vibr. Spectrosc. 30, 237 (2002)

37. I. Coroiu, E. Culea, Al. Darabont, J. Magn. Magn. Mater. 290-291, 997 (2005)

38. T.M. Parrill, J. Mater. Res. 7, 2230 (1992)

39. D. Voll, C. Lengauer, A. Beran, H. Schneider, Eur. J. Mineral. 13, 591 (2001)

40. A. Beran, D. Voll, H. Schneider, J. Eur. Ceram. Soc. 21, 2479 (2001)

41. P. Kansal, R.M. Laine, F. Babonneau, J. Am. Ceram. Soc. 80, 2597 (1997) 


\section{Figure captions}

Fig. 1 DTA and TG curves of $75 \mathrm{SiO}_{2} \cdot(25-\mathrm{x}) \mathrm{Al}_{2} \mathrm{O}_{3} \cdot \mathrm{xM}_{2} \mathrm{O}_{3}$ samples.

(a) $\mathrm{x}=0$; (b) $\mathrm{x}=5 \mathrm{~mol} \% \mathrm{Fe}_{2} \mathrm{O}_{3}$; (c) $\mathrm{x}=5 \mathrm{~mol} \% \mathrm{Y}_{2} \mathrm{O}_{3}$; (d) $\mathrm{x}=5 \mathrm{~mol} \% \mathrm{Dy}_{2} \mathrm{O}_{3}$.

Fig. 2 X-ray diffractograms of $500{ }^{\circ} \mathrm{C}$ calcinated samples.

(a) $\mathrm{x}=0$; (b) $\mathrm{x}=5 \mathrm{~mol} \% \mathrm{Fe}_{2} \mathrm{O}_{3}$; (c) $\mathrm{x}=5 \mathrm{~mol} \% \mathrm{Y}_{2} \mathrm{O}_{3}$; (d) $\mathrm{x}=5 \mathrm{~mol} \% \mathrm{Dy}_{2} \mathrm{O}_{3}$.

Fig. 3 X-ray diffractograms of $1200{ }^{\circ} \mathrm{C}$ calcinated samples.

(a) $\mathrm{x}=0$; (b) $\mathrm{x}=5 \mathrm{~mol} \% \mathrm{Fe}_{2} \mathrm{O}_{3}$; (c) $\mathrm{x}=5 \mathrm{~mol} \% \mathrm{Y}_{2} \mathrm{O}_{3}$; (d) $\mathrm{x}=5 \mathrm{~mol} \% \mathrm{Dy}_{2} \mathrm{O}_{3}$. C- cristobalite; $\mathrm{M}$ - mullite; $\mathrm{Q}$ - quartz.

Fig. 4 FTIR spectra of $500{ }^{\circ} \mathrm{C}$ calcinated samples.

(a) $\mathrm{x}=0$; (b) $\mathrm{x}=5 \mathrm{~mol} \% \mathrm{Fe}_{2} \mathrm{O}_{3}$; (c) $\mathrm{x}=5 \mathrm{~mol} \% \mathrm{Y}_{2} \mathrm{O}_{3}$; (d) $\mathrm{x}=5 \mathrm{~mol} \% \mathrm{Dy}_{2} \mathrm{O}_{3}$.

Fig. 5 FTIR spectra of $1200{ }^{\circ} \mathrm{C}$ calcinated samples.

(a) $\mathrm{x}=0$; (b) $\mathrm{x}=5 \mathrm{~mol} \% \mathrm{Fe}_{2} \mathrm{O}_{3}$; (c) $\mathrm{x}=5 \mathrm{~mol} \% \mathrm{Y}_{2} \mathrm{O}_{3}$; (d) $\mathrm{x}=5 \mathrm{~mol} \% \mathrm{Dy}_{2} \mathrm{O}_{3}$.

Fig. 6 The $400-1700 \mathrm{~cm}^{-1}$ range of FTIR spectra recorded from the samples calcinated at $500{ }^{\circ} \mathrm{C}$ (left) and $1200{ }^{\circ} \mathrm{C}$ (right).

(a) $\mathrm{x}=0$; (b) $\mathrm{x}=5 \mathrm{~mol} \% \mathrm{Fe}_{2} \mathrm{O}_{3}$; (c) $\mathrm{x}=5 \mathrm{~mol} \% \mathrm{Y}_{2} \mathrm{O}_{3}$; (d) $\mathrm{x}=5 \mathrm{~mol} \% \mathrm{Dy}_{2} \mathrm{O}_{3}$. 

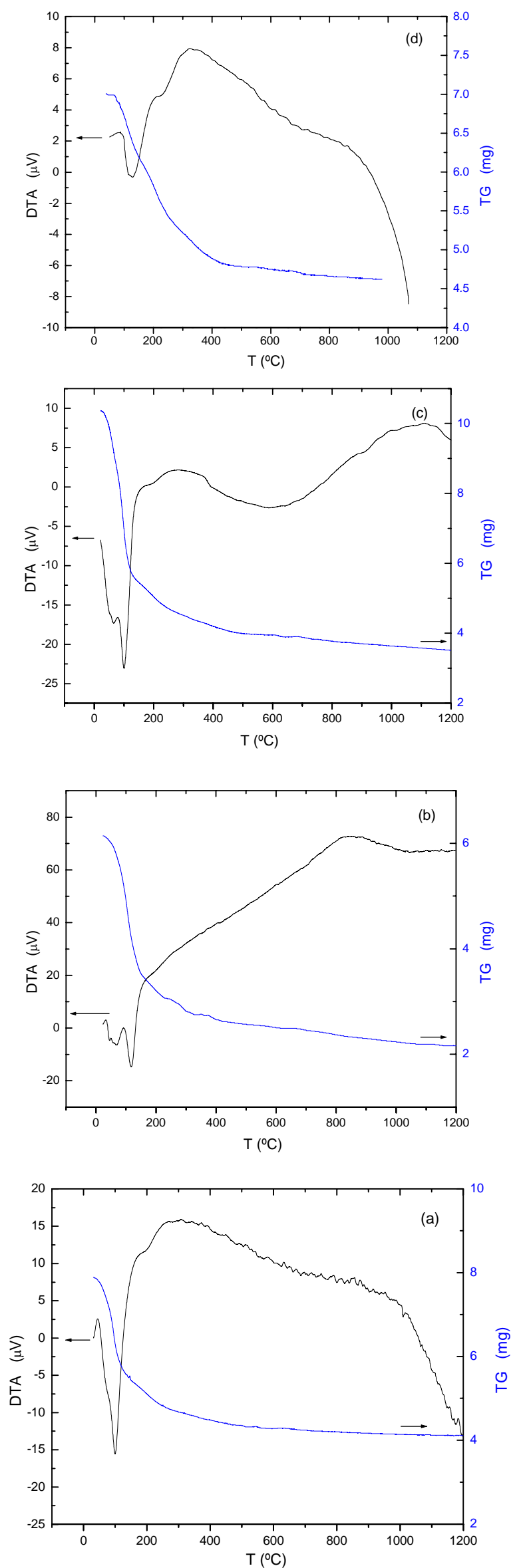

Fig. 1 


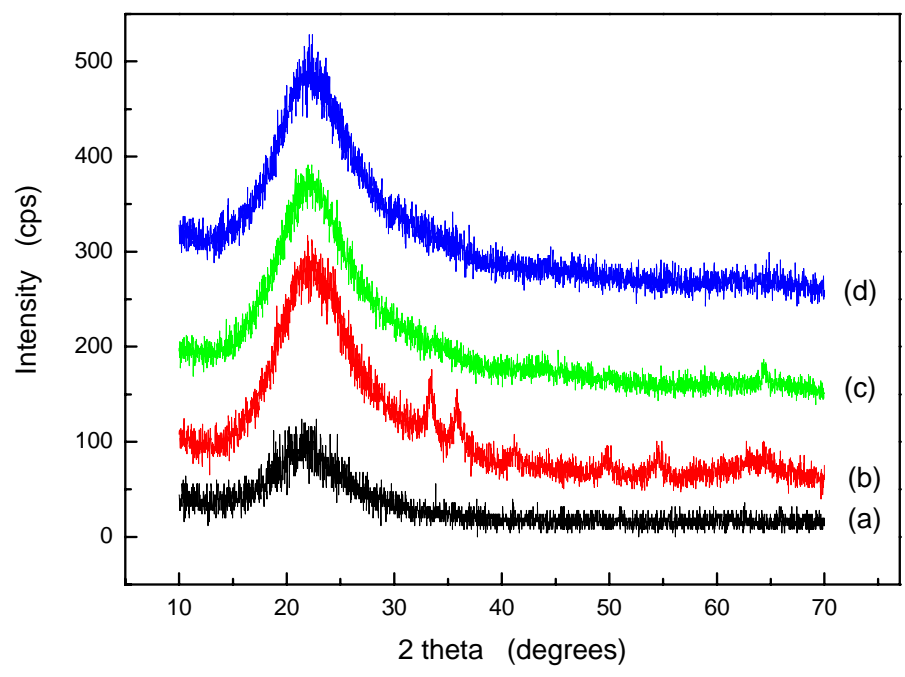

Fig. 2 


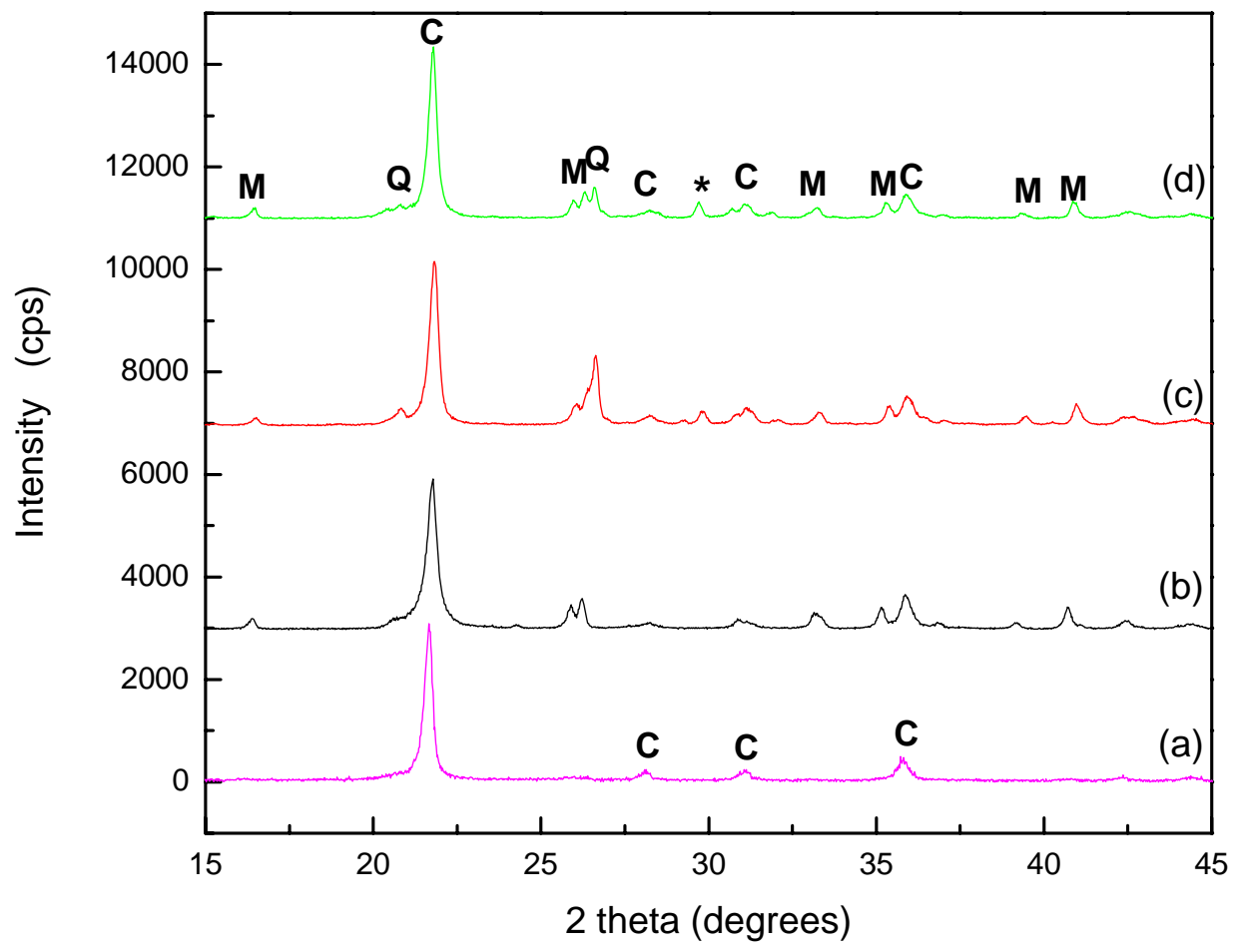

Fig. 3 


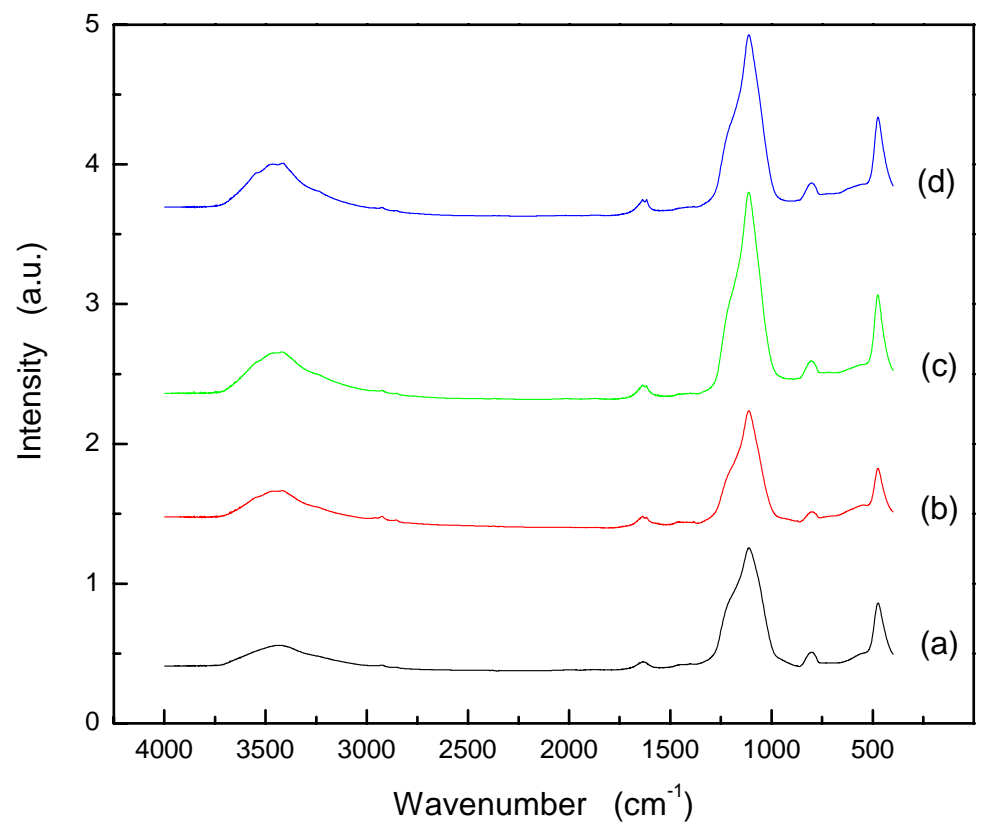

Fig. 4 


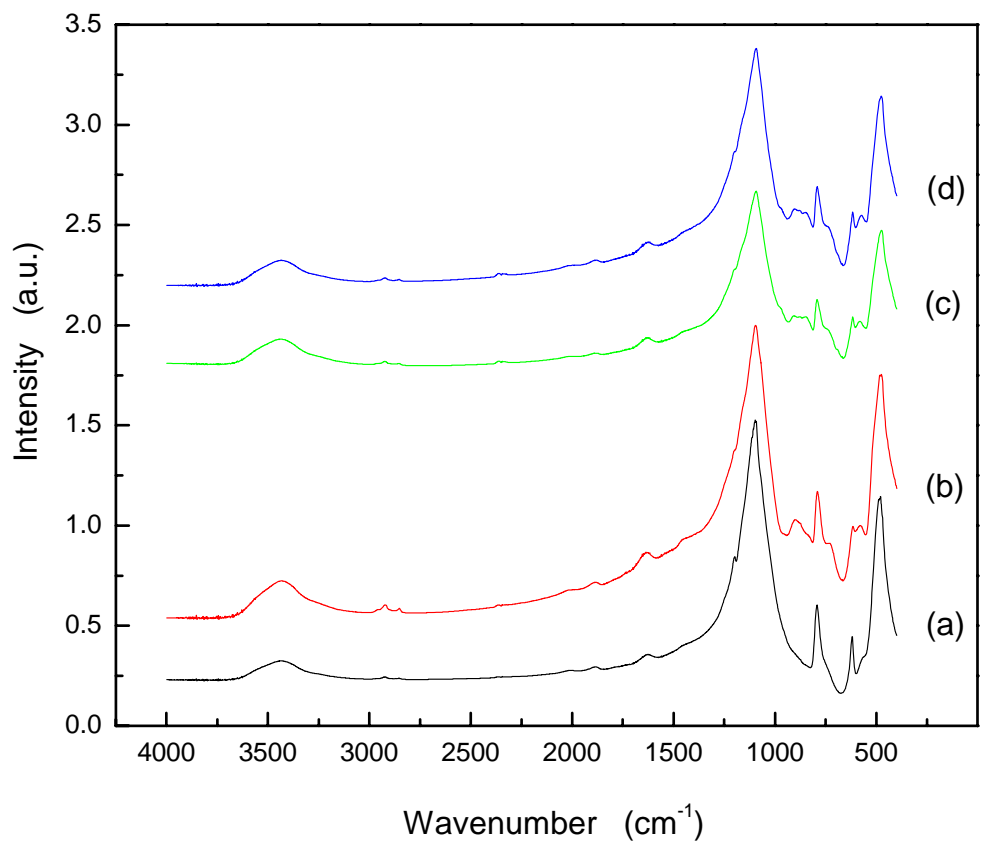

Fig. 5 

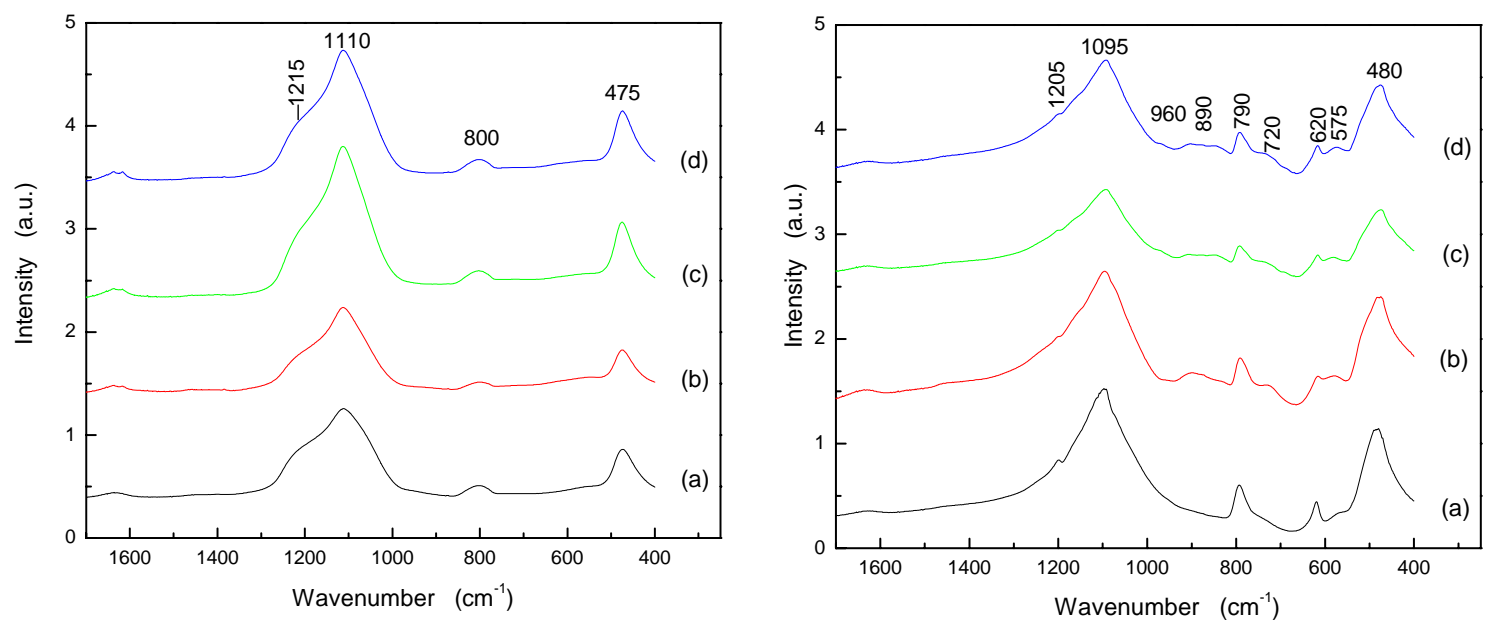

Fig. 6 